\title{
Environmental impacts of public policies in Campo Grande, MS: the case of Lajeado stream environmental protection area
}

\author{
Impactos das políticas públicas ambientais em Campo Grande, MS: o caso da \\ área de proteção ambiental do córrego Lajeado
}
Impacts des politiques publiques de l'environnement en Campo Grande, MS: le cas de Lajeado volet zone de protection de l'environnement Impactos de las políticas públicas del medio ambiente em Campo Grande, MS: el caso
del área de protección ambiental de Lajeado corriente

\author{
Helder Pereira de Figueiredo* \\ Michel Ângelo Constantino** \\ Cristiane Camargo Sanches** \\ Reginaldo Brito da Costa**
}

Recebido em 18/05/2016; revisado e aprovado em 12/08/2016; aceito em 12/09/2016

DOI: http:/ / dx.doi.org/10.20435/1984-042X-2016-v.17-n.4(13)

\begin{abstract}
The post-agenda 2015 of the United Nations has focused on the environment based on the definition of Sustainable Development Goals (SDGs). This study aims to analyse which were the positive and negative externalities generated by public policies in the environmental scope between 2000 and 2015 in the Environmental Protection Area (EPA) of the Lageado area in Campo Grande, MS, from photographic records, satellite images and direct survey with beneficiaries.

Key words: EPA; public perception; sustainability; inefficiency government.

Resumo: A agenda pós-2015 da ONU tem como foco o meio ambiente na definição dos Objetivos de Desenvolvimento Sustentável (ODS). Este estudo tem como objetivo analisar quais as externalidades positivas e negativas geradas pelas políticas públicas de âmbito ambiental entre 2000 a 2015 na Área de Proteção Ambiental (APA) da região do Lajeado em Campo Grande, MS, a partir de registros fotográficos e imagens de satélite e pesquisa direta com beneficiários.

Palavras-chave: APA; percepção pública; sustentabilidade; ineficiência governamental.

Résumé: L'agenda post-2015 des Nations Unies met l'accent sur l'environnement dans la définition des Objectifs de Développement Durable (ODD). Cette étude vise à analyser les externalités positives et négatives attendues générées par les politiques publiques pour cadre environnemental entre 2000-2015 dans la Zone de Protection de l'Environnement (ZPE) de la région Lajeado à Campo Grande, MS, à partir de documents photographiques et des images satellite et enquête directe auprès des bénéficiaires.

Mots clés: ZPE; perception publique; developpment durable; inefficacite gouvernement.

Resumen: La agenda post-2015 de las Naciones Unidas se centra en el medio ambiente en la definición de los Objetivos de Desarrollo Sostenible (ODS). Este estudio tiene como objetivo analizar los factores externos positivos y negativos previstos generados por las políticas públicas de marco ambiental entre 2000 a 2015 en el Área de Protección Ambiental de la región Lajeado en Campo Grande, MS, a partir de los registros fotográficos y las imágenes de satélite y la encuesta directa de los beneficiarios. Palabras-clave: APA; percepción pública; sostenibilidad; gobierno ineficiencia.
\end{abstract}

\section{INTRODUCTION}

The public policies permeate human actions which somehow impact on public goods. In order to ensure the environmental sustainability, it is necessary to create rules which limit their use and protect the environment for the current and future generations.

\footnotetext{
* Instituto de Perícias Científicas, Campo Grande, Mato Grosso do Sul, Brasil.

** Universidade Católica Dom Bosco, Campo Grande, Mato Grosso do Sul, Brasil.
} 
One of the fundamental aspects of the legacy of public policies are their achieved results. Each policy or program hasits economical and social purpose qualitatively and quantitatively defined, having the community and the city as its main beneficiaries.

In literature, there are several ways of measuring range, impact or results of a governmental program or public policy, based on its goals and beneficiaries. One of the most used methods to know the externalities caused by governmental intervention is to analyze data over time, in time series showing the before and after implementation.

In the case of preservation areas, one exhaustedly used way by specific studies is the georeferenced comparison of the area, before implementation and the results over time, also researching how the direct beneficiaries understand the externalities caused by governmental intervention.

Ferreira's (2006) studies were fixed in the Permanent Preservation Area and in public policies in relation to their essential ecological functions whereas Rosa (2011) dealt with legal analysis and their context in governmental policies. The liability and public policies in the environmental area of Amazonas state were discussed by Braz (2006).

This article aimed to analyze which were the positive and negative externalities generated by public policies in the environmental scope between 2000 and 2015 in the contribution basin region of the Lajeado Stream in Campo Grande, MS, from photographic records and direct survey with beneficiaries of the region.

As specific complements, the study also tries to identify the environmental public policies which affected the same region between 2000 and 2015, the main goals of those public policies and evaluate if the aims have been achieved.

In order to develop these purposes, the paper has been divided into this introduction, literature review, methodology, results and final considerations.

\section{PUBLIC POLICY: DEFINITIONS AND THEORY}

The public policies and the policy makers' decisions have been theoretical and empirical fields of study and research for decades. In theory, the public policy or the action public program generated by public policy is the tool by which the governmental entity plans and meets the needs of its citizens through defined actions by its constitution. Public policy establishes the course of the development of a nation, a region, a microregion, a state, a city and reflects in the institututions generated by this development determinants, namely, the quality of life of the population.

Public policies outline their own state planning aimed at achieving public interest: therefore, it is not a matter of simple governmental priorities election, but the concretion of option already carried out by the legislator (FERREIRA, 2006).

Before creating pubic policies, one nation must meet the international treaties and guidelines of the world development. The United Nations Organization (UN) have defined the highpriority challenges for the elimination of poverty and hunger of the planet and have organized eight Objectives of the Millennium Development, associated with implementation of health, sanitation, education, housing, promotion of gender equality and environment policies.

In the case of public policies with environmental nature, it is the legislator's responsibility the elaboration of environmental programs and laws giving concreteness to the Standards of the Socioenvironmental Order. It is certainly a complex activity because they are actions and goals to ensure the current and future sustainability of specific environmental systems of each region and microregion. 
In regions and municipalities, there are suitable programs for the implementation of regional policies through intermunicipal consortium tools, covering several municipalities, starting from economical- ecological zoning.

The municipalities are ordered by the Master Plan and their economicalecological zoning defined as a tool of Environmental National Policy, also suitable for territorial ordering with development and occupation standards. It must not be forgotten the importance of economical-ecological zoning in the municipality internal scope (where decision-makings will be taken for its implementation) as a way of delimitation of areas for definitions of uses, protections, which is the empirical field of this study.

\section{SUSTAINABILITY CHALLENGES}

In 2000, the Cupula of Millennium, which brings together leaders from 189 countries, promoted the Declaration of Millennium, organized by UN and defined the guidelines for the world development. To Feres and Reis (2014), these guidelines do not address in an integrated manner the conservation of natural resources. To the authors, the environmental issue is addressed in a limitated way. The goal 7 , which deals specifically with environment, does not mention the question of the management of natural resources and the targets associated with environmental sustainability lack objectivity and scientific theories. The post-2015 development agenda, which will succeed the Millennium Development Goals (MDG) will have the challenge to integrate the sustainability to other development dimensions (FERES; REIS, 2014).

This macro look that global policies direct to the countries are deployed in microregional and municipal policies to establish actions in a feasible level that meets the results in a macro or global extent.
The environmental policies are created from international guidelines that have sustainability as their main goal. The policy of creation of the Environmental Protection Areas (EPAs) in Brazil is a deployment of the Millennium goals in a municipal level, mainly in areas where there is effective relevance for the population.

The challenge of sustainability is in the population increase and in the way urban areas affect the environment. Following the MDG, which were outlined in 2000 by the Millennium Cupula promoted by UN, it was created in the city of Campo Grande, state of Mato Grosso do Sul, in 2001, the EPA of the Lajeado Stream Springs (Lajeado EPA), with the aim of protecting the water resources which integrate one of the sources that supply the city. A thorough scientific study was carried out in 2008, depicting an inventory of the existing situation in Lajeado EPA. Among these findings, environmental liabilities have been identified.

The analysis of the current situation of each of the environmental liabilities reported in that study was the object of this research, aiming to evaluate if interventions for the remediation and/ or recuperation of those liabilities would have been performed. If so, if they would have been efficient in the effective elimination of the found problems .

\section{THE EPA OF THE LAJEADO STREAM SPRINGS (LAJEADO EPA)}

The Environmental Protection Area of the Lajeado Stream Springs - Lajeado EPA, located in Campo Grande, capital of the state of Mato Grosso do Sul, was created through the Municipal Decree n. 8265,27 th July, 2001. It is a conservation unit belonging to the Sustainable Use group whose aim is to basically reconcile the sustainable use of natural resources with the human presence in the protected area. 
In this region, there is a diversified occupation which comprehends local public roads, gatherers, arterial fast traffic streets, commercial and industrial establishments, farming activities and recreation rural properties and also open and closed residential settlements; the latter is one type of occupation that has happened more frequently lately, which are large encampments in usually sparcely occupied areas of easy acess (YOUSSEF; MALTA, 2006).

Human occupation has been a cause for great concern due to lack of adequate management in implementation, not to mention the stage of operation of open urban settlements, closed residential condominiums, comercial and industrial establishments as well as rural activities related to farming and leisure.

There are great possibilities for the occupations and population density within the limits of the Lajeado EPA to entail damaging effects for the springs which integrate the Lajeado contribution basin, where there is capture of about $12 \%$ (twelve per cent) of water which supplies the city of Campo Grande, MS, according to data from the Management Plan of Springs Lajeado Stream Environmental Protection Area - Lajeado EPA (PMCG; AGUAS GUARIROBA S.A., 2012), hereafter only referenced as Management Plan.

In this context, it is essential to analyse the externalities resulting from the creation of the EPA and over time and also to check the perception of population concerning the creation of public policy and their results.

\section{METHODOLOGY}

\subsection{Environmental liabilities analysis}

\subsubsection{Comparison from the Management Plan data}

The Management Plan conducted in the Lajeado EPA was, amongst other elements, aimed to identify the environmental liabilities observed on November 20, 2008 within its 5,235 hectares of surface area through thirty-eight photographs, in which the geographical location, the details of each of the observed problems and then proposed measures for their recuperation or remediation are described.

From these data, which were demonstrators of the status quo at the time of the Management Plan (MP) surveys, were carried out new visits in each one of the places, in order to check the present situation and above all, if there was no reversal in the framework of previously observed environmental agression. This comparison was made on-site with direct identification and photographic fixing in each of the situations, that is, the one described in the MP (november 20, 2008) and the identification in the research, whose surveys were carried out on November 13 and 14, 2015.

\subsubsection{Comparison from Satellite Images}

In support of in loco observations, were carried images of comparison studies of years 2008 and 2015, extracting data from forest cover on both dates. The 2008 data are those contained in the MP, especially in pictures 4.2.1.c (Vegetal Cover) and 4.3.1.a (Use of Soil). The 2015 data were supported by technical work developed by Folhes (2015).

\subsection{Perception of Public Policies Externalities with the beneficiaries}

Aiming to research how the direct beneficiaries understand the externalities caused by governmental intervention linked to the creation of Lajeado EPA, a survey was held with closed questions (Likert Scale, wide gradation levels), targeted to specific publics, among them government officials involved in licensing activities, monitoring and environmentam sustainability (organs such as SEMADUR, IMASUL and IBAMA) or supervision and punishment of these 
activities (Public Ministry, Law Enforcement Agencies and Judicial Expertise), dwellers in one of the Campo Grande Environmental Protection Areas, (besides the Lajeado EPA, there are the Guariroba and Ceroula EPAs), people connected to universities, class entities (CREA, OAB and CAU), social organizations and also business entities with activities in the area of influence of EPA.

The survey was sent to 1248 people in one of the segments above, by using the plataform of Google Drive Forms ${ }^{\circledR}$. There was no need of the respondent's identification. The first aspects covered by the survey were the ones related to socio-economic parameters. They were then presented questions about the National System of Conservation Units (SNUC, in portuguese) were presented, with the objective of identify the level of absorption level of the same by the respondentes. Covered also the analysis of the effectiveness of the legislation (Law 9985/2000). The third stage achieved specific questions about the Environmental Protection Areas (EPAs) as a whole, that is, trying to prospect if there perception of efficacy due of the Law 6902/1981. The last stage was based on questions related to the Municipal Decree of Campo Grande, MS, 8265/2001, which came to specifically establish the Lajeado EPA.

The systemic analysis of the responses provided allowed to identiy lhe level os awareness of the population regarding environmental issues in general and also as to the Lajeado EPA specifically.

\section{RESULTS AND DISCUSSION}

\subsection{Environmental liabilities results}

\subsubsection{Comparison from Management Plan data}

For identification of the situation of environmental liabilities which were detected in the research and compared to the ones observed in the surveys which supported the Lajeado Epa Management
Plan, the same locations, listed in annex 11 of that environmental inventory, were covered, obtaining the following results:

\subsubsection{Silting of the riverbed by decanters material of the Guariroba EPA}

The comparison of the pictures below reveals that: a) there was some natural regeneration (silting reduction), without full success (liability not totally reversed); b) the physical structure of the dissipation box needs maintainance; $c$ ) there were not interventions of closing in the Permanent Preservation Area (PPA), which was necessary to avoid cattle trampling in the protected area.

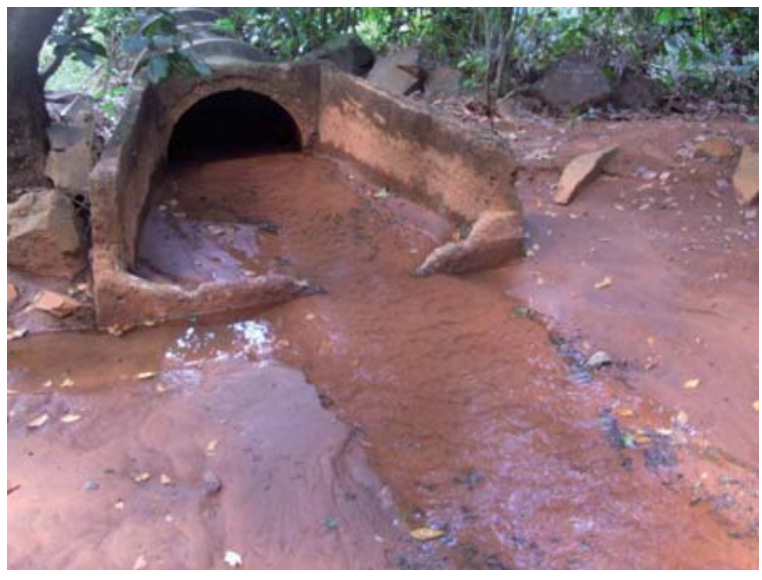

Figure 1 - Picture on November 20, 2008.

Source: Manegement Plan. Type of liability: silting of watercourse/ silting and vegetation burial of PPA. Generated cause: service activity

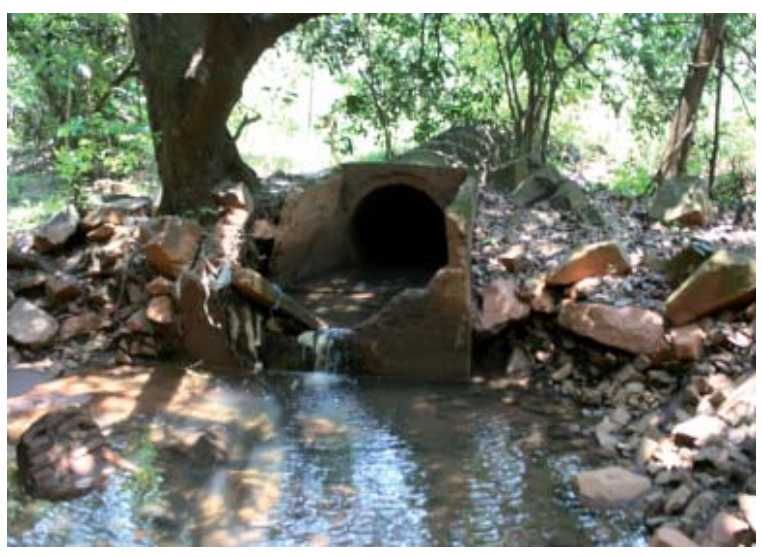

Figure 2 - Picture on November 13, 2015, in the same location (at the point of coordinates UTM 756,061 × 7,732,935) 
Source: Research data. The liability continues as well as its deterioration by activity or generated cause of services.

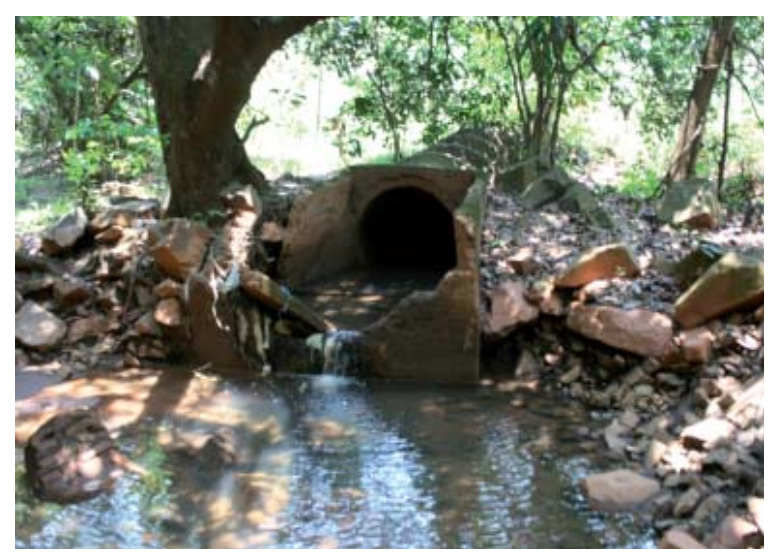

Figure 3 - Picture on November 20, 2008

Source: Management Plan Type of liability: contamination by effluents and residues / release of sewage in spring area/ watercourses. Generated cause: urban occupation.

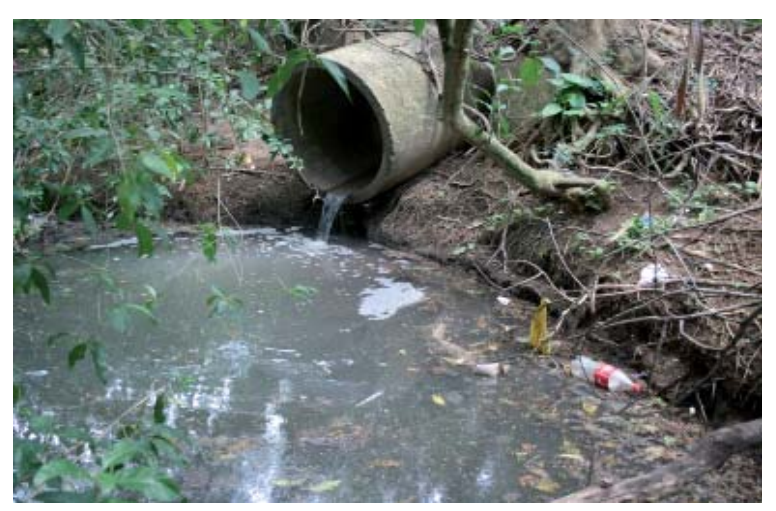

Figure 4 - Picture on November 14, 2015, in the same location, at the point of coordinates UTM 755,293 x 7.734.581

Source: Research data.

The comparison of the above pictures reveals that:a) There were not interventions intended to the environmental liability elimination although without maximizing the preexistent problem; $b$ ) It is verified a small vegetal regeneration in the PPA, not being enough for the recuperation of water quality; c) The release of sanitary sewage in the spring remains and it was also observed that urban waste is loaded to river-bed.

\subsubsection{Abandoned loan area with sheet} rosion processes and in low density grooves, probably formed during the railway building, long completed

The comparison of the pictures below reveals that: a) There were no interventions for the elimination of the problem, although there was an apparent increase of the preexisting problem; b) It was observed sparse undergrowth regeneration. The sandy terrain is very susceptible to erosion processes. Leaching process.

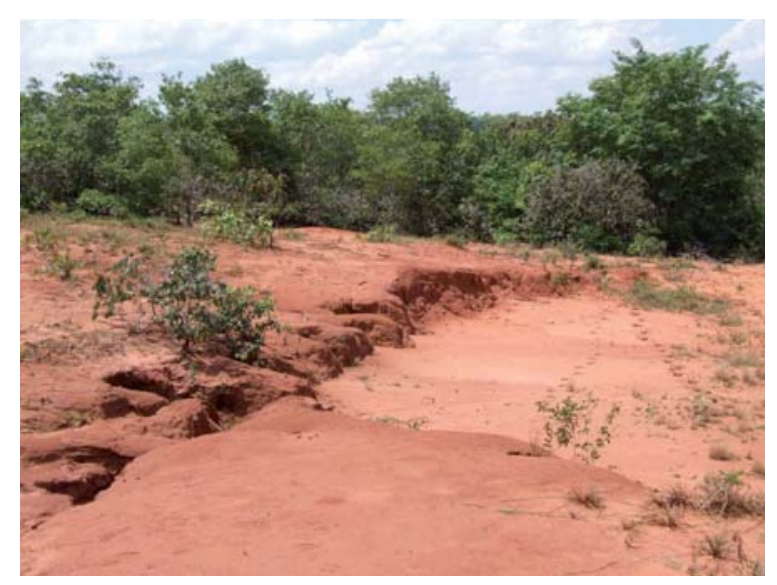

Figure 5 - Picture on november 20, 2008 Source: Manegement Plan The type of liability is the sheet erosion and in grooves, where there is a not recovered support unit. Generated cause: existing building site.

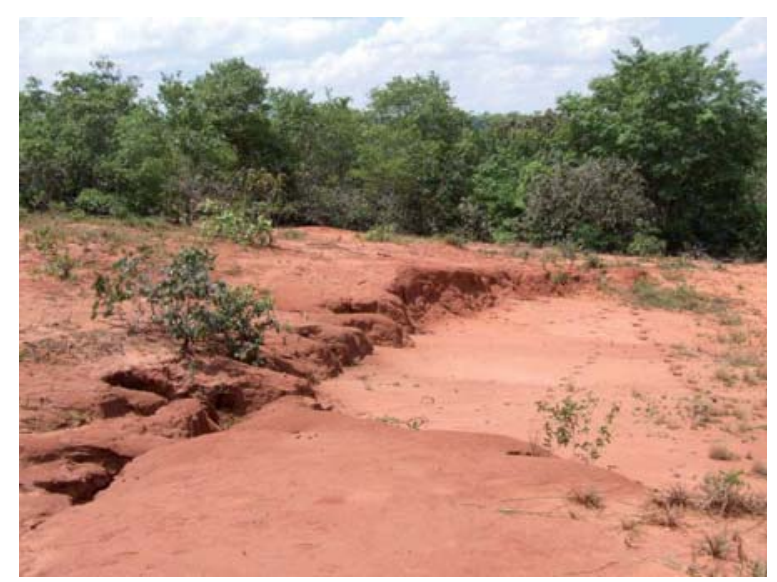

Figure 6 - Picture on November 13, 2015, in the same location, at the points of coordinates UTM 759,257 x 7,732,393

Source: Research data. 
The presented visual comparisons, which have merely sample nature, reveal that very few were the interventions intended to mitigation or remediation of environmental liabilities.

\subsubsection{Comparison from satellite images}

This subitem is aimed to compare the situations of Use of the Soil and Vegetation Index, from satellite images for the years 2008 and 2015, according to the calculation carried out by Folhes (2015).

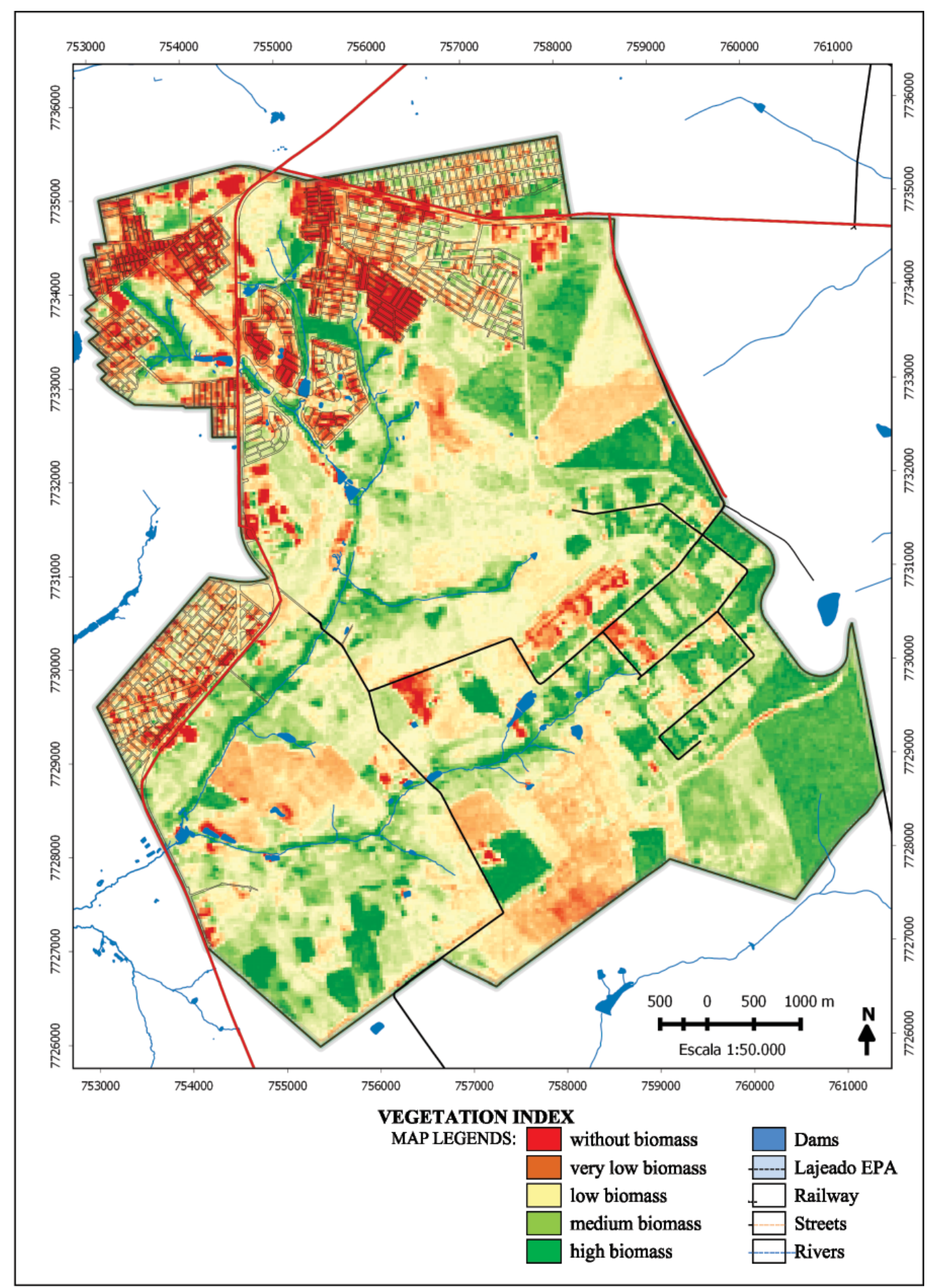

Figure 7 - Vegetation Index Map on December 18, 2008 Recorded image from TM/ Landsat- 5 sensor, covering the spectral bands 3,4 and 5 in orbit/point 225/74. Source: FOLHES (2015). 


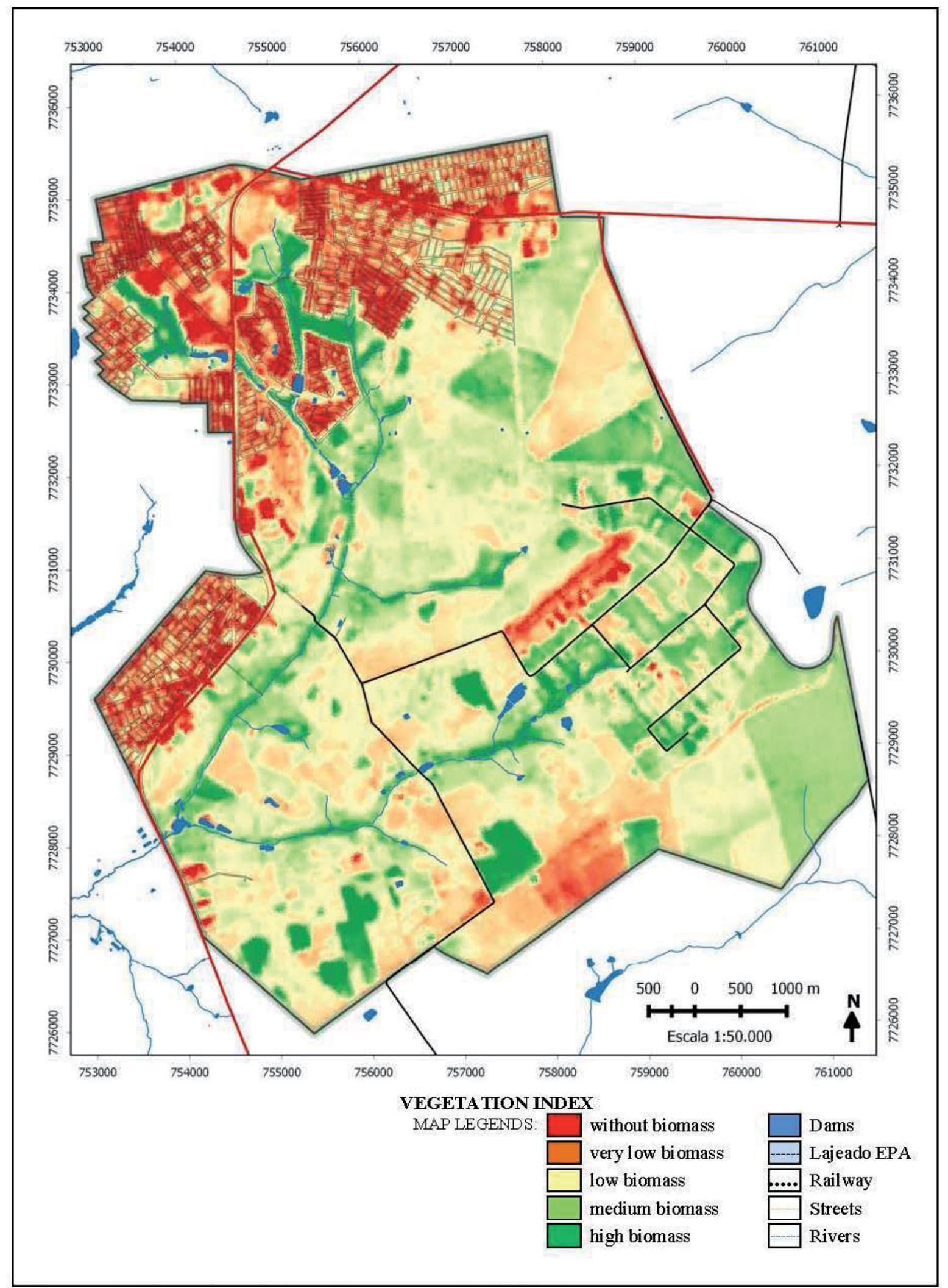

Figure 8 - Vegetation Index Map on august 16, 2015. Recorded image from OLI/ Landsat-8 sensor, covering the spectral bands 2,3, 4, 5, 6, 7 and 8 in orbit/point 225/74. Source: FOLHES (2015). 


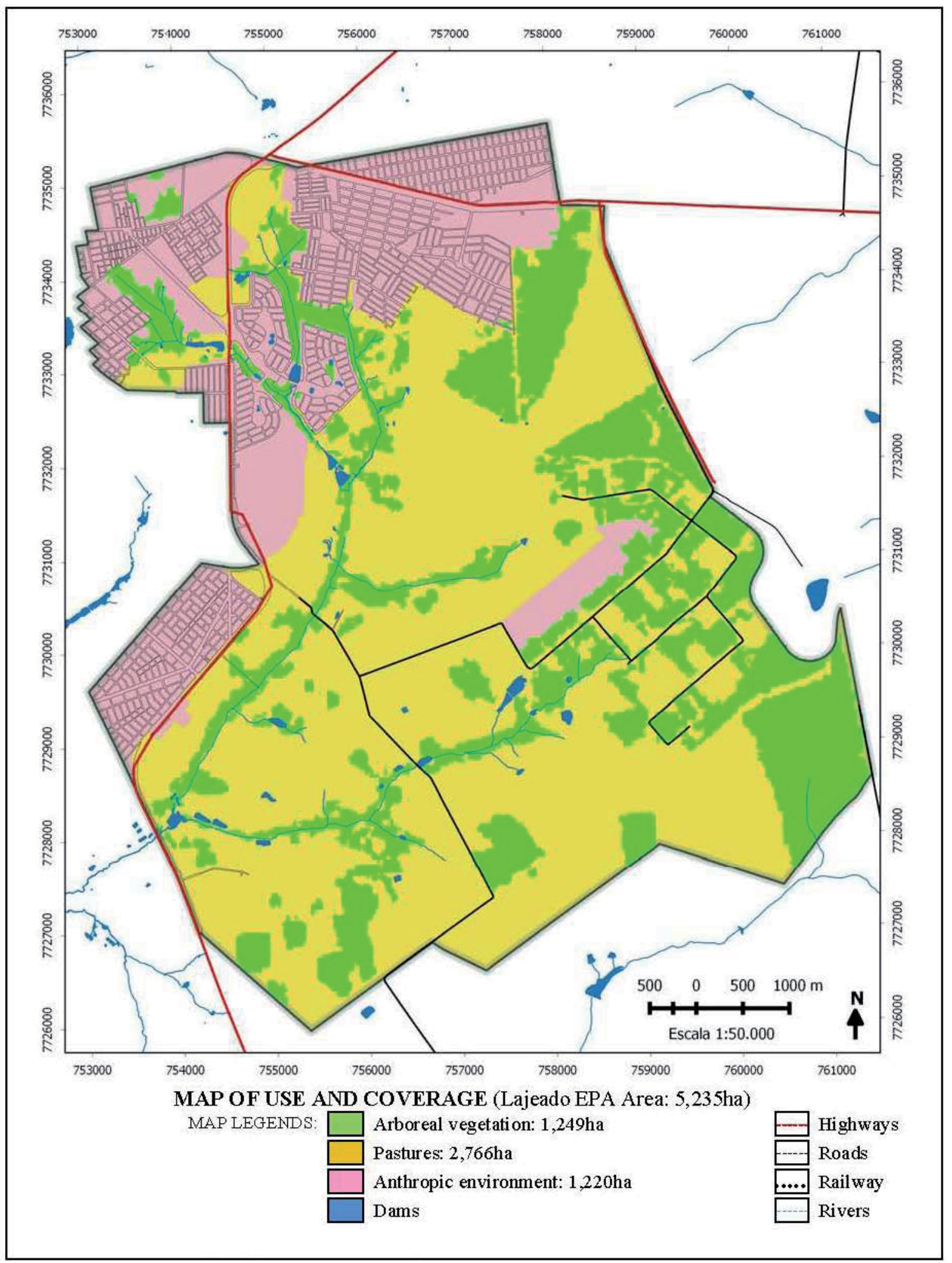

Figure 9 - Map of Soil Use on December 18, 2008. Recorded image from TM/Landsat-5 sensor, covering the spectral bands 3, 4 and 5 in orbit/point 225/74. Source: FOLHES (2015). 


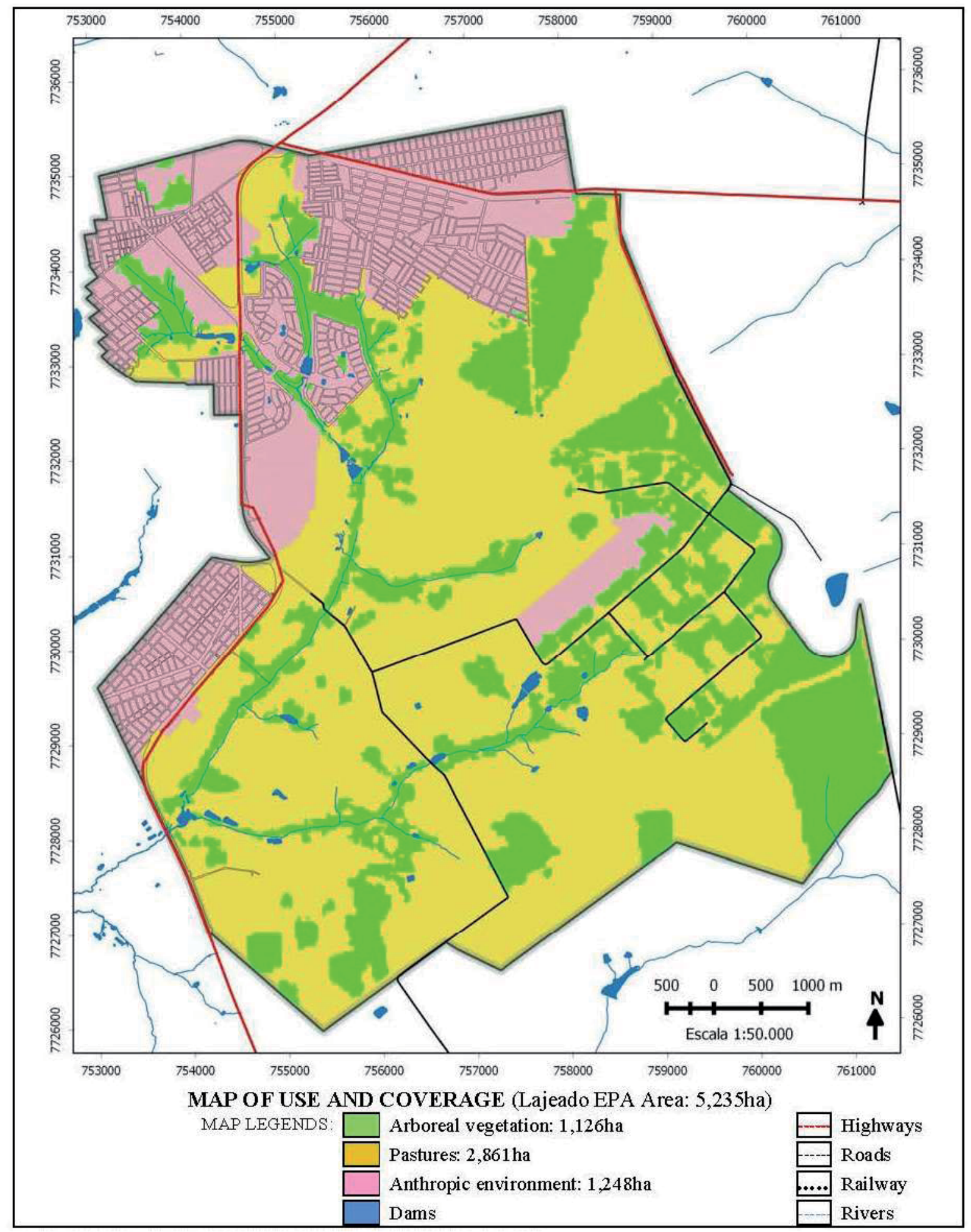

Figure 10 - Map of Soil Use on August 16, 2015. Recorded image from OLI/Landsat-8 sensor covering the specral bands $2,3,4,5,6,7$ and 8 in orbit/point 225/74. Source: FOLHES (2015). 
The comparison of the satellite images reveals us that: a) between 2008 and 2015 there was a reduction of 1,249ha (23,85\% of the EPA total area) to 1,126ha $(21,50 \%$ of the total area) in arboreal vegetation existing within the limits of EPA Lajeado; b) In 12/18/2008, $52,8 \%$ of EPA territory was occupied by natural or planted pastures, raising to $54,6 \%$ on $08 / 16 / 2015$; c) Among the dates, there has been a progress of real state developments in areas surrounding the headwaters Lajeado stream contributors; d) The PPA, in both analyzed passages, are not but narrow strands of riparian vegetation along water bodies; e) In both passages, it is observed an important forest fragmentation, a clearly inappropriate circumstance to preservation of biodiversity of the region.

\subsection{Analysis of Perception of Individuals}

For the analysis of perception of individuals, the empirical research included 118 stakes, $83,1 \%$ of the respondents are over 31 years old and 58,55 of the total are male. Having high schooling levels, $91,6 \%$ of the participants have university degree, 57,65 were born in the Middle-West region and 65,3\% have lived in Campo Grande for more than ten years. The on-line surveys have been sent to people directly involved in environmental issues of the county and of the state of Mato Grosso do Sul, where $65 \%$ of the total revealed that they know the area and work with this theme.

\subsubsection{National System of Conservation Units (SNUC)}

In relation to specific issues concerning the SNUC - Law 9985/2000, it was questioned if SNUC has considerably contributed to the preservation and restoration of the diversity of natural ecosystems. The recorded data from Graphic 1 show that 50,9\% partially or totally agree with the SNUC job for the preservation and restoration of diversity and approximately $11,8 \%$ disagree and the others could not answer.

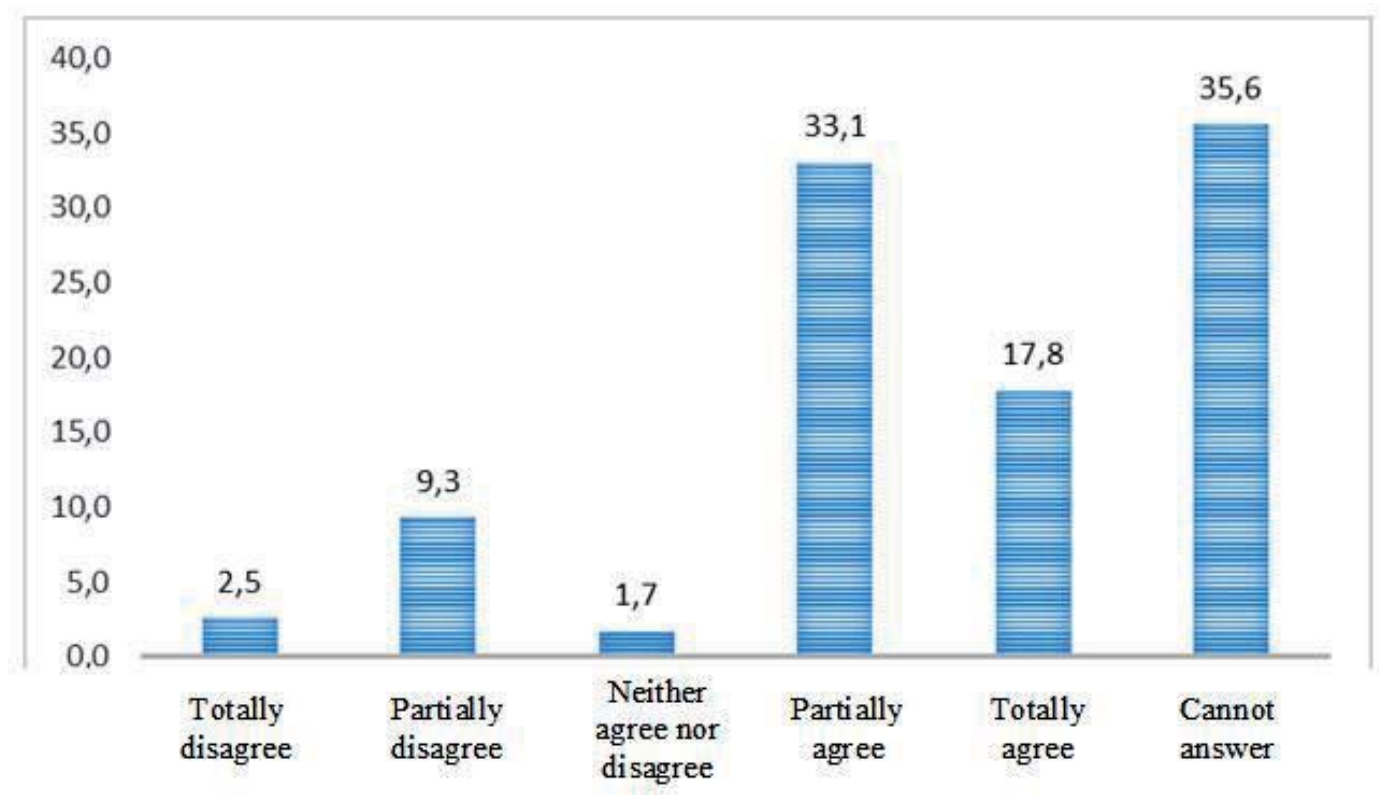

Graphic 1 - Perception about the SNUC contribution to the preservation and restoration of diversity.

Source: Research data 
Being questioned about SNUC efficiency, the interviewee have been asked if only SNUC is enough for the environment to be effectively protected, due to the malpractice of fiscalization carried out by the environmental control organs.

Nearly $63 \%$ of the interviewed agree that SNUC cannot provide protection and natural preservation, according to Graphic 2.

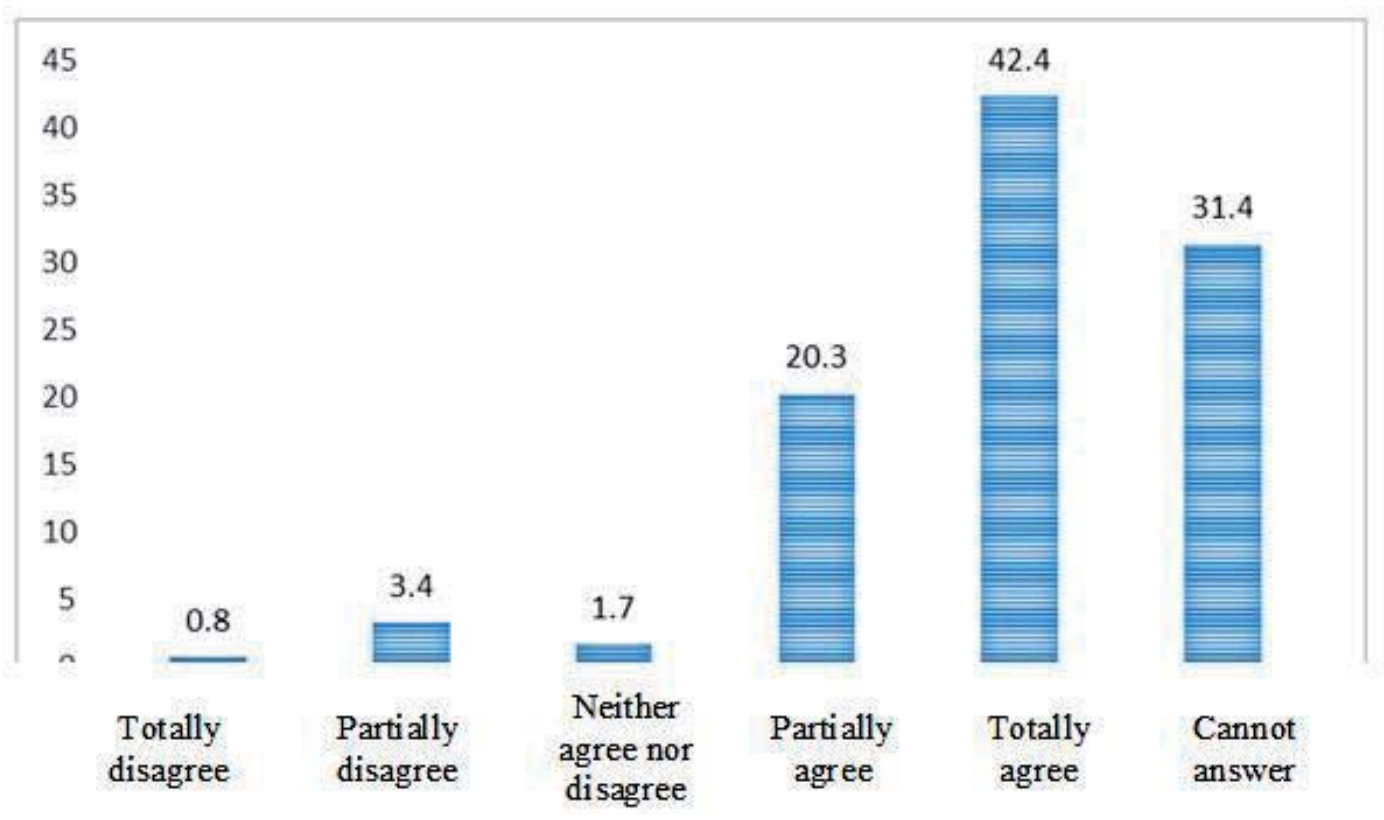

Graphic 2-SNUC is not enough for the environment to be protected because of insufficient supervision by environmental agencies.

Source: research data.

Evaluating the perception in the empirical field study about the Law 6902/1981 which regulates the EPA, it has been questioned if the fact of the article 9th of the Law to establish rules to limit or prohibit implementation and operation of potentially polluting industries capable of affecting water sources inside EPAs is enough for the effective protection of water resources which supply one population. The Graphic 3 shows that $45 \%$ of the interviewee disagree that the Law is enough for the protection of the water resources while $35 \%$ agree that it is enough and effective. 


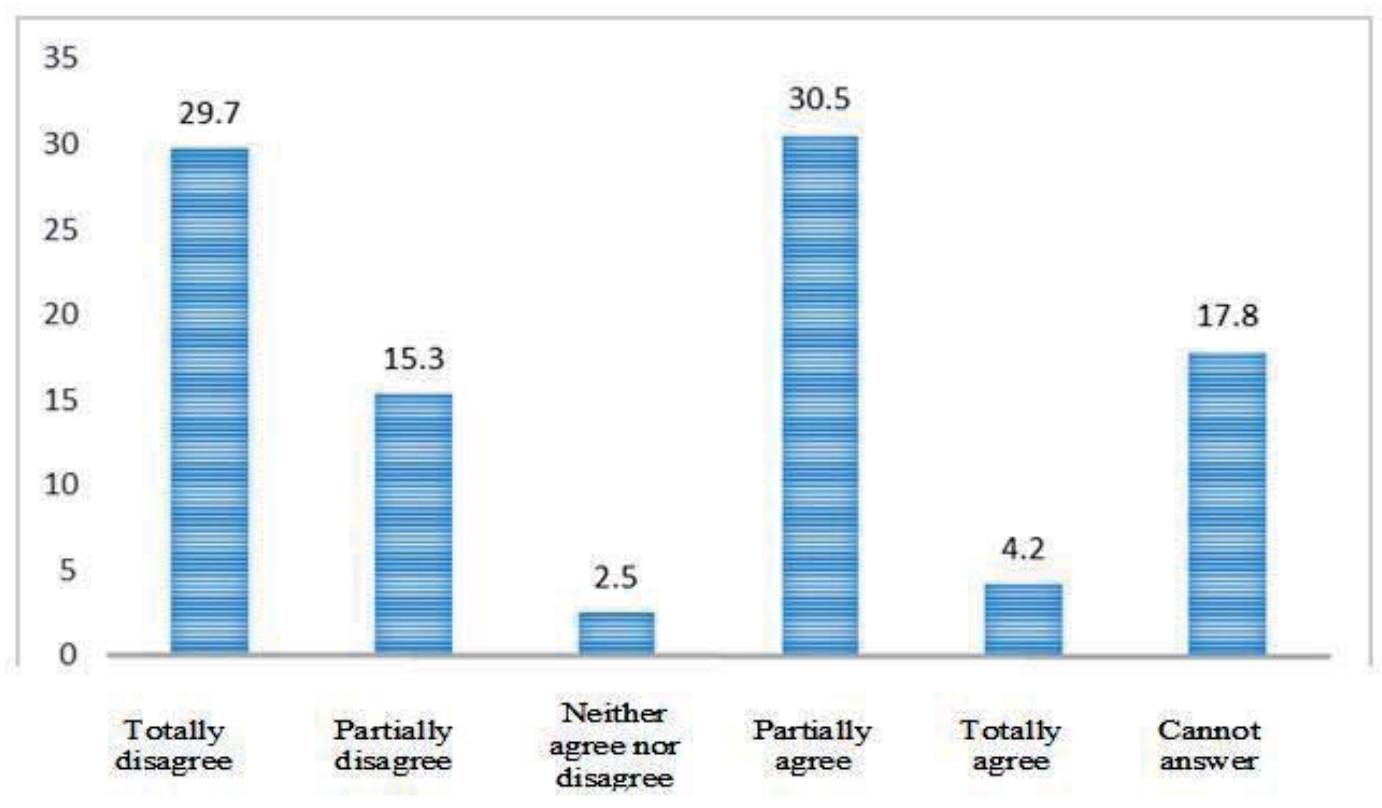

Graphic 3: Perception of the item "a" of article 9 of Law 6902/1981 to establish rules to limit or prohibit the operation of industries that affect water resources within EPA.

Source: Research data.

\subsubsection{PERCEPTIONS CONCERNING LAJEADO EPA INSTITUTION}

It hss been analysed in this item the perception of the interviewed people towards the objective of the decree of EPA creation in Campo Grande and the support of the supervision and execution of protection process. As it happens in several public policies, the inefficiency and failure to comply with the aims and purposes made in the creation scope, the
Lajeado EPA is one more unsuccessful item of the list in the individuals' perception.

The research results show that, as the Lajeado EPA decree aims to restore, protect and conserve the springs formed by the Lajeado Stream Basin which supply the city, is not fully fullfilling their duty.

Graphic 4 shows that $36,4 \%$ of the interviewee disagree that EPA protection purpose is being achieves while 35,6\% agree that it is being partly achieved. 


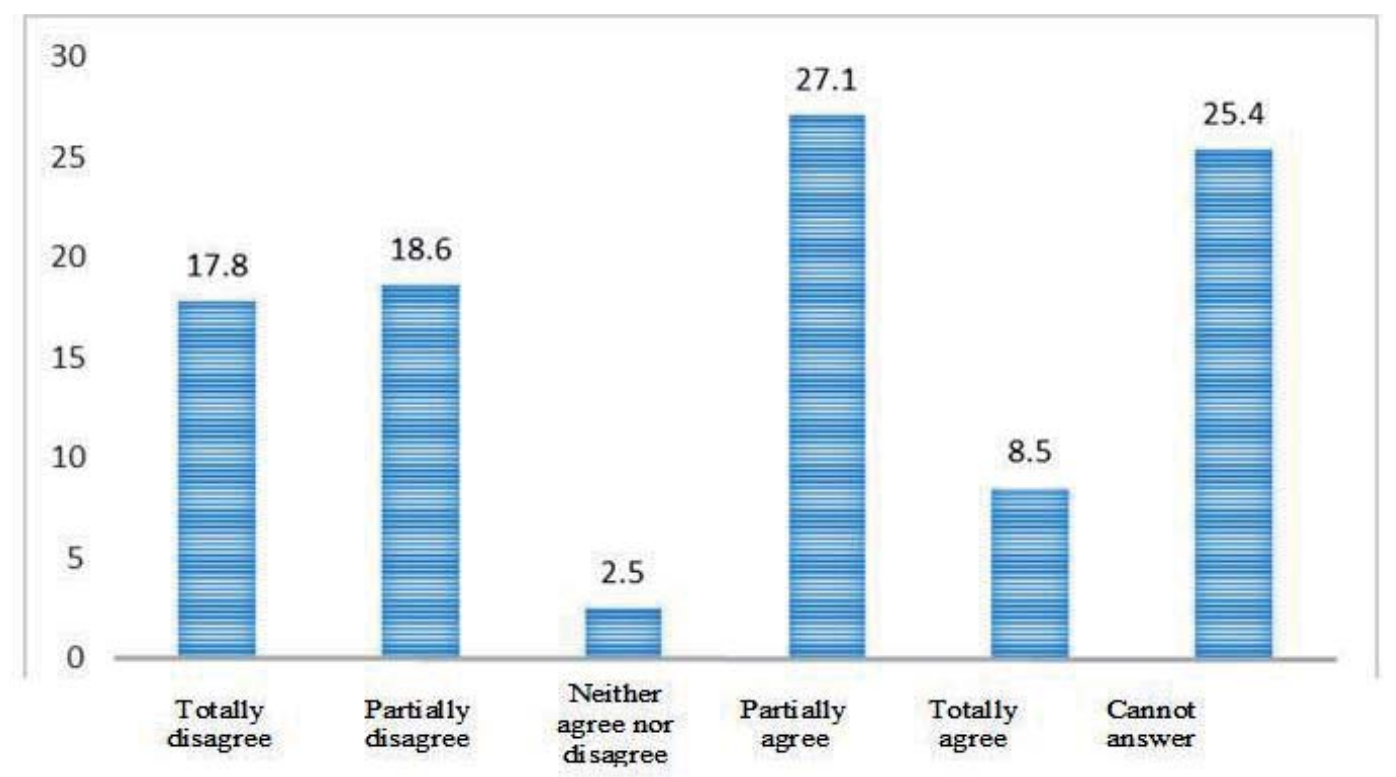

Graphic 4: The Lajeado EPA purpose of restoring, protecting and conserving the springs formed by the Lajeado Stream Basin which supply the city.

Source: Research data.

6.2.3 Perceptions concerning Local Supervision

Another kind of perception was to analyse how the respondents evaluate the environmental supervision at Lajeado EPA carried out by Municipal Secretaria of Sustainable Environment and Development (SEMADUR) of Campo Grande, MS.

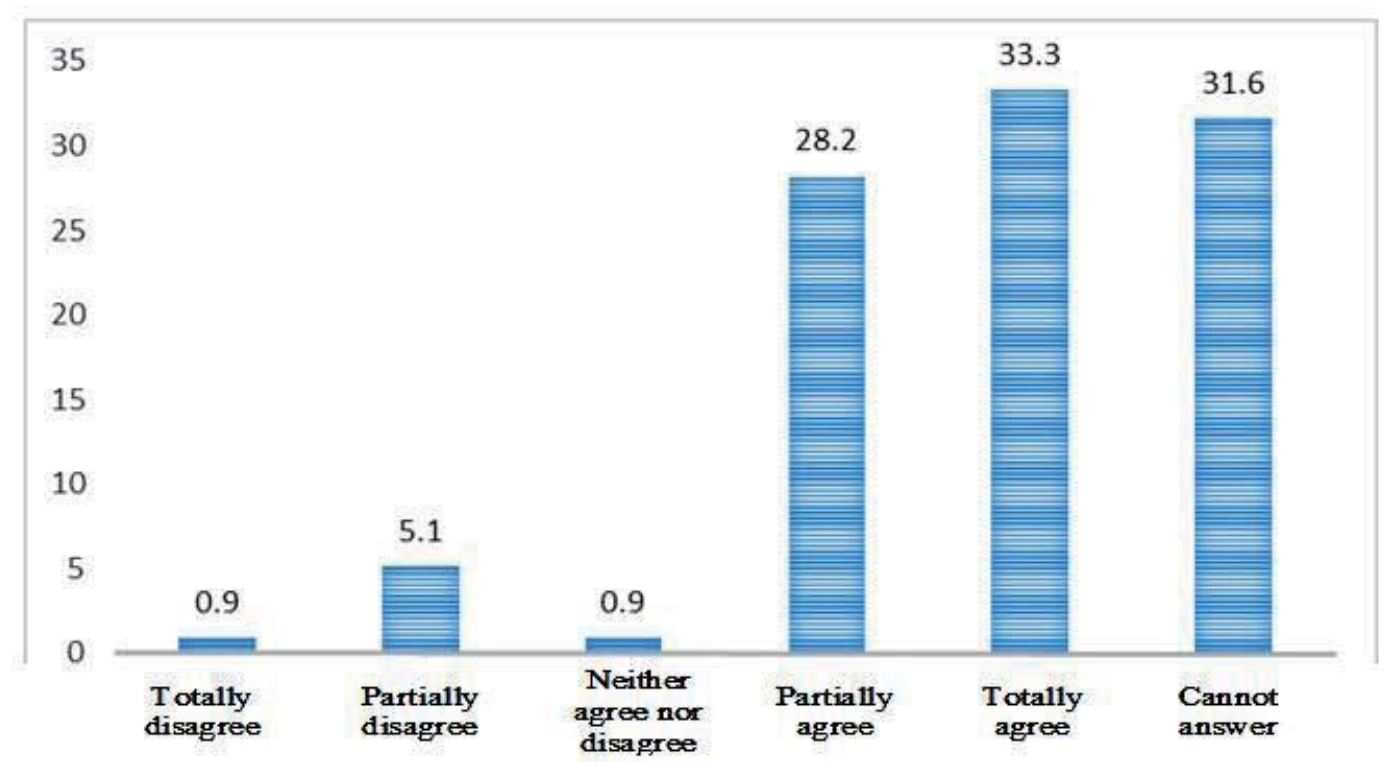

Graphic 5: Inefficiency due to lack of SEMADUR supervision agents Source: Research data. 
$61,5 \%$ of the interviewee agree that lack of supervision is a deterrent factor to achieve better results while $6 \%$ disagree. The predominant feeling is that the supervision carried out by public agents is not efficient owing to lack of human resources for its implementation. The EPA environmental supervision carried out by SEMADUR is not efficient resulting from the insufficient material resources, which prevents effective use of technology in environmental control. The combination of these data allows for a systemic view that the inefficiency of the public action supervision would be due to lack of personnel associated with scarcity of material resources for the implement.

\section{FINAL CONSIDERATIONS}

Since the creation of Lajeado EPA constitutes a public policy designed to protect the environment in general and specifically the springs which contribute with approximately $12 \%$ of surface water to the city of Campo Grande, MS, in line with the Millennium Goals and its efficiency would be evaluated through positive actions, the objectives have not been achieved, considering that the liabilities which were evidenced in 2008 were not reverted until 2015. There was also reduction in the Arboreal Vegetation Index within the protection area, persisting faecal waste release in the contributor streams springs. Furthermore, not protected permanent protection areas and intense forest fragmentation have been evidenced.

It is observed that the feeling among people who are directly or indirectly connected with environmental issues is that the simple creation of legal tools does not entail any benefit in the institution of public policies to be effective as implementation institutes of life quality of population in general.

Conclusively, there is little optimistic prognosis of public policies in the
Lajeado EPA, which makes it imperative to prescribe some pragmatic actions for implementation of good environmental practices, among of which stand out: a) need to enhance the public agents'professionalization involved in the environmental supervision and management in the city of Campo Grande, MS, including better pay and autonomy to perform their activities; $b$ ) the public organs involved in the environmental supervision and management must have technological support availability (satelitte images management with high resolution and in real time, drones, helicopters, etc.) and infrastructucture for the development of their work; c) a public policy must be implemented for the pay of environmental services (PSA, acronym in Portuguese), designed to incentive environmental interventions from landowners, among which, the implementation of terracing and contour lines in areas susceptible to erosion, closing of the Permanent Preservation Areas and the connection of forest fragmentation via vegetation corridors which minimize the carrying of solid and liquid waste harmful to human health.

\section{REFERENCES}

BRAZ, Sebastião Ricardo Braga. Exigibilidade e políticas públicas na área ambiental no estado do Amazonas. 2006. 174f. Dissertação (Mestrado em Direito Ambiental) - Programa de Pós-graduação em Direito Ambiental, Universidade do Estado do Amazonas, Manaus, AM, 2006.

FERES, José; REIS, Eustáquio. A agenda de desenvolvimento pós-2015: a questão ambiental no contexto do desenvolvimento sustentável. In: MONASTERIO, Leonardo Monteiro; NERI, Marcelo Côrtes; SOARES, Sergei Suarez Dillon (Ed.). Brasil em Desenvolvimento 2014: estado, planejamento e políticas públicas. Brasília: Ipea, 2014. v. 2. FERREIRA, Ximena Cardozo. Regularização fundiária em área de preservação permanente: 
a resolução CONAMA 369/2006. In: CONGRESSO DE DIREITO URBANOAMBIENTAL, 18-20 out. 2006, Porto Alegre, RS. Anais... Porto Alegre: CORAG, 2006. p. 45.

FOLHES, Marcelo Theophilo. Resultados do mapeamento de uso e cobertura da terra para os territórios das Áreas de Proteção Ambiental dos Mananciais do Córrego Lajeado (APA do Lajeado). Campo Grande, MS: IbiGeo - Geociência Aplicada, 2015. 7p.

PREFEITURA MUNICIPAL DE CAMPO GRANDE (PMCG); ÁGUAS GUARIROBA S.A. Plano de Manejo da Área de Proteção
Ambiental dos Mananciais do Córrego LajeadoAPA do Lajeado. Campo Grande, MS: PMCG, 2012.

ROSA, M.D. A Relevância ambiental das áreas de preservação permanente e sua fundamentação jurídica. Planeta Amazônia. Revista Internacional de Direito Ambiental e Políticas Públicas, n. 3, p. 83-95, 2011.

YOUSSEF, L. R., MALTA, F. J. N. C. Área Residencial em Zona de Amortecimento na Apa da Serra da Mantiqueira - Região do Vale do Paraíba, SP. Revista Ciências Humanas, Taubaté, v. 12, n. 2, p. 75-89, jun./dez. 2006.

\section{Sobre os autores:}

Helder Pereira de Figueiredo: Perito Judicial e Criminal - Engenheiro Civil, Engenheiro de Segurança do Trabalho, Advogado, Contador e Biólogo. Mestre em Biotecnologia (Genética de Populações). Doutor em Ciências Ambientais e Sustentabilidade Agropecuária. E-mail: hpfigueiredo@ipcms.com.br

Michel Ângelo Constantino: Pesquisador e Professor na Universidade Católica Dom Bosco (UCDB), Programa de Mestrado e Doutorado em Ciências Ambientais e Sustentabilidade Agropecuária; Programa de Mestrado em Desenvolvimento Local. E-mail: michel@ucdb.br

Cristiane Camargo Sanches: Médica Veterinária. Doutora em Ciência Animal. E-mail: cristianesanches@hotmail.com

Reginaldo Brito da Costa: Professor da Universidade Católica Dom Bosco (UCDB), Programa de Mestrado e Doutorado em Ciências Ambientais e Sustentabilidade Agropecuária; Programa de Mestrado em Desenvolvimento Local. E-mail: reg.brito.costa@gmail.com 